\title{
1119 小型無線ヘリコプタの制御一ベンチ飛行テスト䒧置の開発一
}

\author{
Control of Portable Radio Controlled Helicopter
}

- Development of a Device for Bench Flight Test-

\author{
$\bigcirc$ 学 林田祐宏(福岡大院) \\ 正 林 長軍(福岡大) \\ 证下川哲司(福岡大) \\ 正尾崎弘明(福岡大) \\ 学 浅田直孝(福岡大院)
}

Masahiro HAYASHIDA,Fukuoka Univ,8-19-1,Nanakuma,Jo-nan-ku,Fukuoka

Chang-jun LIN, Tetuji SIMOGAWA, Hiroaki OZAKI and Naotaka ASADA,Fukuoka Univ

Key Words : Portable Helicopter, Fright Test Device, Radio Control, Neural Network

\section{1 緒言}

加工·組み立てを主目的としない輸送ロボットや、観測ロボットに は広い空間を自由に移動できる機能か㴗求されることが多い。また 輸送、観測には静止した状態(ホバリング)を実現できるロボットが 必要になる。無人へリコプ夕は、すでに国内外で多く製造され農薬 散布、写真撮影から火災消化、火山活動の監視などに利用されてい る(1)が、ここでは、ポータブルなエンジンを搭載した模型用ラジ コンヘリコプタをコンピュータで制御できることを目指して研究を 進めている。対象が小型軽量で婹に入手できるため操作時のトラ ブルなどの事故による損失は少ないが、外乱や負荷変動およびエン ジンの出力変動などの影響を受けやすく、そのため制御方法を確立 することは容易ではない。本論では、実験室内で安全に制御方法を 検討するための飛行テスト装置を開発することを検討している。電 動へリコプタを対象とした装置の検討例(2) はあるが、パワーのあ るエンジン搭載機に使える装置としたこと、センサ信号を用いて拘 束運動を非拘束運動として模擬するシミュレ一夕を構成しているこ とに特徴がある。また、この装置の一部の機能を用いてニューラル ネットワークを用いたホバリング制御の検討例も示す。

\section{2 小型ヘリコプタの実蜍置の検討と作成}

小型へリコプタの実験装置を作成するにあたって、限られた空間 でどのような装置にするかを決定する必要がある。そこで現実的な 1）非拘束型、その結果を踏まえた2）部分拘束型の 2 種類の実験 装置について考える。

1）非拘束型実験装置について

非拘束型実験装置を考えるにあたり、まず限られた空間内で安全 に実験出来るかどうかを検証する必要がある。非拘束型実験装置を 検証するために簡単な試験装置を作り、ヘリコプ夕に装着して室内 で飛行させてみた。この試験装置は、実験か河能力否かを検討する ためのものなので、計測装置は一切取り付けていない。

1 つ目は拘束しない代わりに壁と接触してもいいように機体を囲す 筲型のものを作った。2 つ目は装置の中心から放射状に伸びた 6 本 のアームの先端と地面に置いてある鉄のアングルとを紐で結ぶこと で壁への接触を避け、高度の制限をしたここの 2 つの装置を用いて、 非拘束型の実験装置の作成が可能力否かを検討したここの 2 つの試 験装置から得られた結論は、壁や天井と接触したときの安全性と計 測方法に問題があることか確認され、2）の部分拘束型の実験装置 について作成検討する。

2）部分拘束型実験装置について

拘束する自由度は少ないほうが良く、とくに重要な高度について は移動できるようにしてある。その他の運動については、ユニバサルジョイント、フォーストルクセンサとコンピュータによるシミ ユレーションによってへリコプタの運動を推定し、飛行制御する方 法をとった。Fig.1 に装置の全体図を示す。この装置は、へリコプ 夕にユニバーサルジョイントを取り付け、ポテンショメータで機体 の傾きを計測し、その下にあるフォーストルクセンサを用いて機体

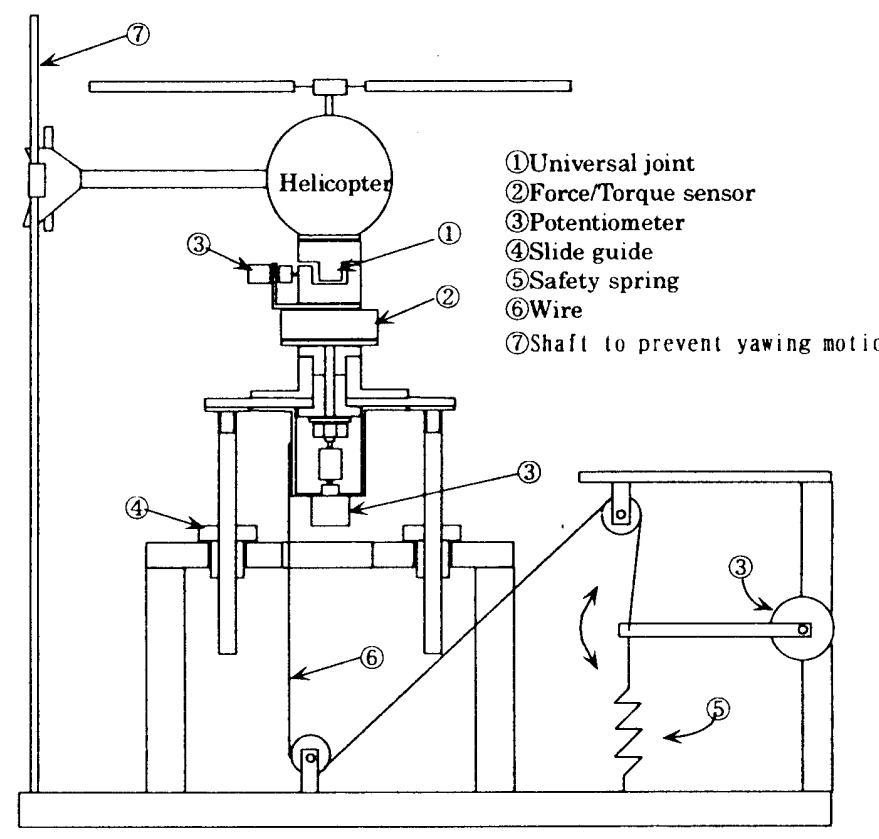

Fig.1 Flight test device for portable helicopter が発生する力を計測し、シミュレーションで機体の移動量を推定す る。さらにフォ一ストルクセンサの下に回転機構を設けることで機 首の向きを変えることが出来るようにしてある。これもポテンショ メー夕によって回堭角度を検出する。埵直力向の運動は、直動軸受 けを用いて滑らかに動くようにした。高度は機体に取り付けたワイ ヤを、滑車を介してポテンショメー夕を回転させ換算することによ つて検出する。ワイヤには高度を制限する機能も持たせている。ま た、地面効果 (3) を考虑して地面から少し高いところにへリコプタ を設置している。

\section{3 操作系の構成}

Fig.2 に制御系を示す。本研究で使用する操作系にはラジコンに 使用される送受信機を用い、送信機のレバー操作によって発生する 出力電圧をコンピュー夕に代替させる方式をとる。基本的にはへリ

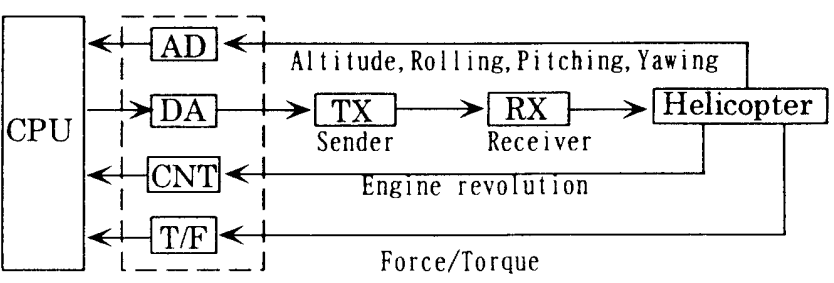

Fig.2 Control system

コプタの運動はポテンショメータを用いて計測する。ポテンショメ 一夕から得られるへリコプタの各運動を $\mathrm{A} / \mathrm{D}$ 変換し換算して得ら

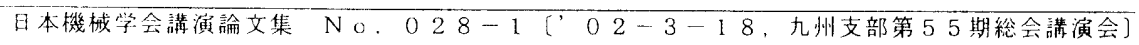


れたデータをもとに制御系で操作量を計算し、D/A 変換によって送 信機（TX）の電在入力部に入力し、受信機 (RX) に送信する。送 信された操作量はあらかじめ設定された固有の比例ゲインにしたが って、ヘリコプタの操作系(サーホ)を駆動する。

\section{4 制缽系の構成}

制御系として PID 制御の特性を学習させた二ューラルネットワー ク（以下 NN）をもちいる例を示す。この制御系ではまず、PID ントローラによる操作量を NNに学習させ、途中から NNに制御系 を切り替えるようにしている。Fig.3に PID 制御系の学習の構成を 示す。ホバリング制御の場合動特性のパ夕ーン化については高度之 操作量を一定時間遅延した信号をそれぞれの入力㕌のユニットに与

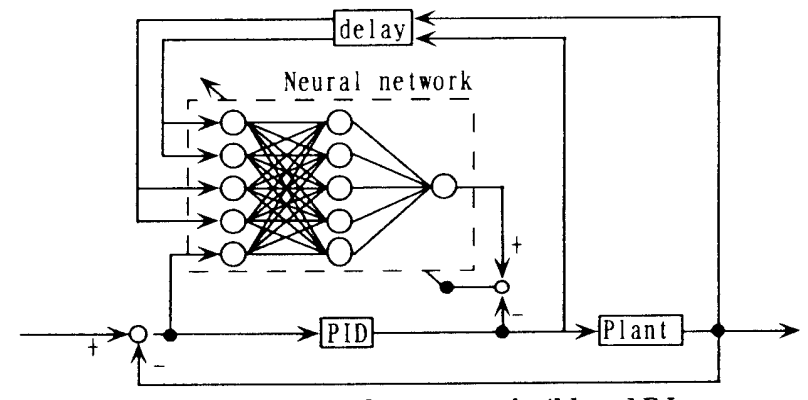

Fig.3 PID control system to build up NN

えている。制御に使用する PID、NN のパラメー夕は実験に基づい て決定する。PD制御系のパラメー夕については比例制御て制御可 能な比例ゲインをもとに限界感度法を用いて各パラメー夕を決定し た。NN制御系は過去の実験デ一夕(4)をもとに決定した。

\section{5 シミュレータの作成}

開発した実験装置は一部拘束状態にあるので、拘束された部分の 運動を補うため、シミュレーションによって擬似的に再現すること で非拘束の飛行制御状態を求める。シミュレーションに必要な運動 方程式は、重力とヘリコプタが発生する推力の釣り合いから求める。 実機用のシミュレータのほかにもう 1 つ制御系の構築に使用する数 学的モデルを用いたシミュレータも作成した。このシミュレータは、 シミュレーションによって得られた結果を実機の実験に利用できる ように、制御系が出力する操作信号を実験機用の電生に変換したあ とヘリコプタの推力に置き換える。この電圧と推力の関係は簡単な 直線式に置き換えたものを用いる。Fig.4 に実験装置を構成する各 装置を示す。安全のためへリコプタのある部屋と制御装置のある部 屋は分離してある。ディスプレイにはシミュレーション結果と各セ ンサからのデータを表示する。

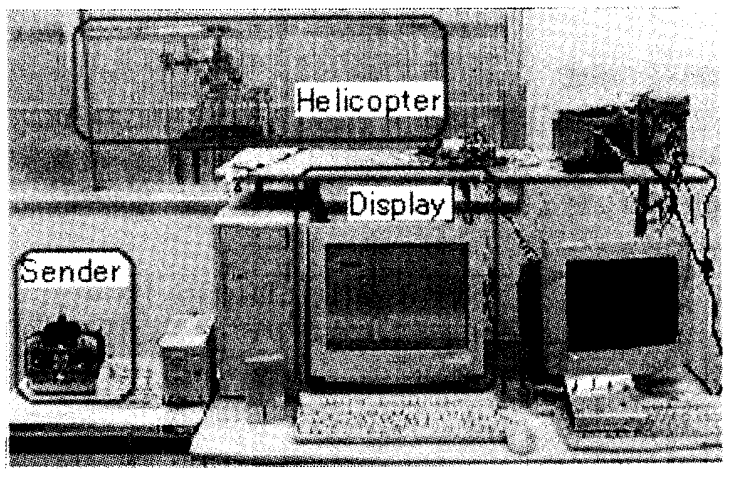

Fig.4 Overview of simulator and controller

シミュレーションの表示には移動量を視覚的にとらえられるような 工夫をした。ディスプレイには機体を模した絵が表示され、その向 き・位置・大きさからへリコプタの状態が把握できるようにしてあ る。機体の傾き(ロ一ル、ピッチ)など同一ピクチャーボックスに表
示しにくいものについては、別にピクチャーボックスを設けて表現 している。その他にフォーストルクセンサより検出される、力・モ 一メントの表示なども可能なように作った。

\section{6 シミュレーション結果}

次に示すシミュレーション結果は数学モデルを用いたシミュレー ションで、NN 制御系の構成を検討するために行った直接制御型 $\mathrm{NN}$ 制御系である。NN の構造は入力層 5、中間層 5、出力層 1 と し、学習倸数などのパラメー夕は過去の実機実験のデ一夕をもとに 決定した。PID 制御系のパラメー夕は実機を用いた実験である程度 の制御結果が得られたデータをもとにして、限界感度法に基づいて 設定している。 Fig.5、Fig.6はサンプリングタイムを50(ms)とし たときのステップ応答で、PID による学習回数をそれぞれ 3 ステッ プ (1300 サンプリング)、 5 ステップ(2100サンプリンク)学習した に後 NNによる単独の制御に移行している。3 ステップ学習後の応 答に比べ5ステップ学習後の応答のほうが目標值に対してオ一バー シュートが少なく目標値によく追従している。

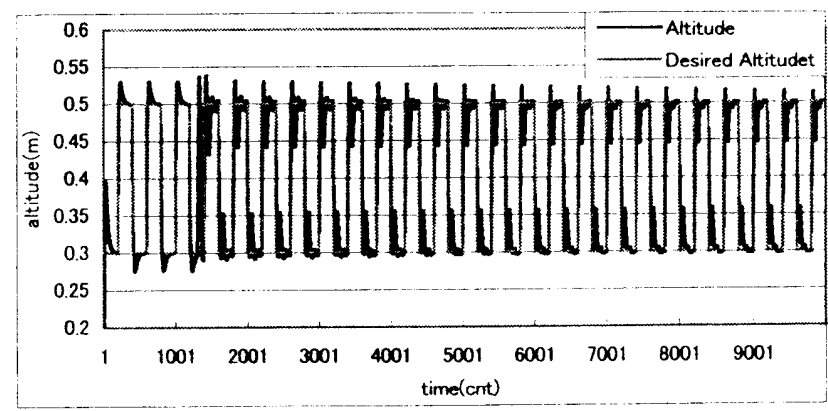

Fig.5 Response of PID and NN control system by simuration (3step learning)

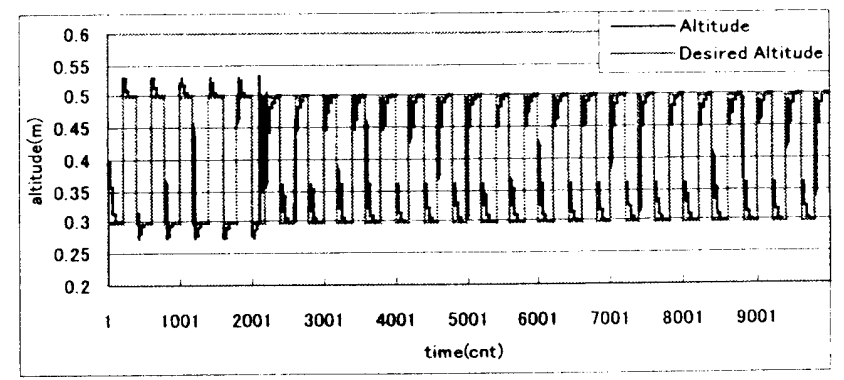

Fig.6 Response of PID and NN control system by simuration (5step learning)

\section{7 結言}

拘束した状態で、可能な限りヘリコプ夕の自由な運動を把握でき るような実験装置を提案した。また、簡単な数学的モデルを用いた シミュレータを作成したシミュレーションによって PDD 制御系の 特徴を学習したNNによる直接制御の有効性を確認した。NNの学 習にはある程度の時間をかけないと良い結果が得られないというこ とがわかつた。今後は㬰機を基にした実験をおこない多自由度化し たときの NN制御系の構造について研究を進める予定である。

\section{参考文献}

(1)菅野道夫,実用化を目指す空中ロボットー無人ヘリコプター,日本 ロボット学会誌 $18-7(2000), 937-940$.

(2) 大山・古田,ラジコンヘリコプタのディジタル制御,計測自動制御 学会論文集,21-2(1985),109-115.

(3)加藤・今永 ヘリコプタ入門 (1998)東京大学出版会.

(4)橋本・林・下川・尾崎,小型ヘリコプタのホバリング制御,日本機 械学会講演論文集,No.008-1(2000),205-206. 